\title{
Incivility Among Radiography Educators in the United States
}

Kevin R. Clark

The University of Texas MD Anderson Cancer Center, krclark@mdanderson.org

Jessyca B. Wagner

Midwestern State University, jessyca.wagner@msutexas.edu

Follow this and additional works at: https://nsuworks.nova.edu/ijahsp

Part of the Medical Sciences Commons

This Manuscript has supplementary content. View the full record on NSUWorks here: https://nsuworks.nova.edu/ijahsp/vol17/iss3/2

\section{Recommended Citation}

Clark KR, Wagner JB. Incivility Among Radiography Educators in the United States. The Internet Journal of Allied Health Sciences and Practice. 2019 Jan 01;17(3), Article 2.

This Manuscript is brought to you for free and open access by the College of Health Care Sciences at NSUWorks. It has been accepted for inclusion in Internet Journal of Allied Health Sciences and Practice by an authorized editor of NSUWorks. For more information, please contact nsuworks@nova.edu. 


\title{
Incivility Among Radiography Educators in the United States
}

\begin{abstract}
Purpose: Medical imaging education must nurture a civil environment for both students and educators. Because faculty incivility can potentially compromise learning and interfere with workplace productivity, this study examined the perceptions of incivility among radiography educators in the United States.

Methods: A survey research method was designed to examine the severity and frequency of incivility among educators teaching in radiography programs accredited by the Joint Review Committee on Education in Radiologic Technology (JCERT). Using a scale of 1 to 4, the participants in this study considered their perceptions of faculty incivility among radiography educators within their respective departments.

Results: Civility has been demonstrated as a perceived problem in this survey. A total of $240 / 1,333$ educators completed the survey, resulting in a response rate of $18 \%$. Only $40.4 \%(97 / 240)$ of the participants in this study perceived that the severity of incivility was not a problem. The majority of the participant perceived civility to be an issue with $23.8 \%$ (57/240) reporting a minor problem; 39/240 (16.3\%) said it was a moderate problem; and $47 / 240(19.6 \%)$ believed faculty incivility is a major problem among radiography educators in the United States. Interestingly, severe uncivil faculty behaviors did not occur as often as behaviors classified as less severe. A very weak negative correlation was found between perceived severity of faculty incivility and age of radiography educators, indicating age increased as the perceived severity of faculty incivility slightly decreased and vice versa.

Conclusions: Faculty incivility is perceived to be occurring among radiography educators in the United States. This study provides a foundation for future research to address various aspects of incivility among imaging sciences and radiation therapy educators in the United States.
\end{abstract}

\section{Author Bio(s)}

Kevin R. Clark, Ed.D., R.T.(R)(QM) is an Assistant Professor and Graduate Education Coordinator with the School of Health Professions at The University of Texas MD Anderson Cancer Center in Houston, Texas.

Jessyca B. Wagner, M.S.R.S., R.T.(R) is an Assistant Professor with the Department of Radiologic Sciences at Midwestern State University in Wichita Falls, Texas. 


\title{
IIIAHSP \\ The Internet Joumal of Allied Health Sciences and Practice \\ Dedicated to allied health professional practice and education
}

Vol. 17 No. 3 ISSN 1540-580X

\section{Incivility Among Radiography Educators in the United States}

\author{
Kevin R. Clark ${ }^{1}$ \\ Jessyca B. Wagner ${ }^{2}$
}

1. The University of Texas MD Anderson Cancer Center

2. Midwestern State University

United States

\begin{abstract}
Purpose: Medical imaging education must nurture a civil environment for both students and educators. Because faculty incivility can potentially compromise learning and interfere with workplace productivity, this study examined the perceptions of incivility among radiography educators in the United States. Methods: A survey research method was designed to examine the severity and frequency of incivility among educators teaching in radiography programs accredited by the Joint Review Committee on Education in Radiologic Technology (JCERT). Using a scale of 1 to 4 , the participants in this study considered their perceptions of faculty incivility among radiography educators within their respective departments. Results: Incivility has been demonstrated as a perceived problem in this survey. A total of 240/1,333 educators completed the survey, resulting in a response rate of $18 \%$. Only $40.4 \%$ (97/240) of the participants in this study perceived that the severity of incivility was not a problem. The majority of the participant perceived incivility to be an issue with $23.8 \%$ (57/240) reporting a minor problem; 39/240 (16.3\%) said it was a moderate problem; and $47 / 240(19.6 \%)$ believed faculty incivility is a major problem among radiography educators in the United States. Interestingly, severe uncivil faculty behaviors did not occur as often as behaviors classified as less severe. A very weak negative correlation was found between perceived severity of faculty incivility and age of radiography educators, indicating age increased as the perceived severity of faculty incivility slightly decreased and vice versa. Conclusions: Faculty incivility is perceived to be occurring among radiography educators in the United States. This study provides a foundation for future research to address various aspects of incivility among imaging sciences and radiation therapy educators in the United States.
\end{abstract}

Keywords: faculty incivility, medical imaging education, and radiography education 


\section{INTRODUCTION}

Academic incivility is often associated with disruptive student behaviors in the classroom that compromise teaching and learning; however, instructors can also engage in uncivil behaviors directed toward students and colleagues that can adversely affect the classroom and workplace..$^{1-3}$ According to the American Nurses Association, uncivil behaviors, such as acting rudely, gossiping, or refusing to help a colleague, violate professional standards and can potentially lead to threatening situations or workplace violence. ${ }^{4}$ In addition, some harmful behaviors can be more overt in nature, such as making offensive remarks or using intimidation to undermine a colleague, while other forms of incivility can be more covert in nature, like failing to intervene or withholding vital information during critical situations. ${ }^{4-6}$ As expected, behaviors considered uncivil to some educators may be deemed less severe or merely unprofessional by other educators.

Imaging sciences and radiation therapy educators should provide a civil learning and working environment for both students and colleagues. Because faculty incivility has the potential to compromise student learning and interfere with workplace productivity, this study examined the perceived prevalence of incivility among radiography educators in the United States. For the purpose of this study, incivility was defined as those faculty behaviors that disrupt student learning and hinder workplace productivity.

\section{LITERATURE REVIEW}

Several electronic databases were used to search for relevant scholarly sources including Academic Search Complete, Cumulative Index of Nursing and Allied Health Literature Complete, MEDLINE Complete, and ScienceDirect College Edition. The search was performed in 2017. Keywords used in the searches included combinations of faculty incivility, medical imaging education, and radiography education. Only 1 peer-reviewed article was identified involving student incivility as perceived by radiography educators. ${ }^{7}$ Because of the lack of research specific to faculty incivility among imaging sciences or radiation therapy educators, additional searches were conducted to locate relevant research articles discussing faculty incivility in other allied health professions and higher education in general. The common themes identified in the literature included faculty-to-faculty incivility and faculty-tostudent incivility.

\section{Faculty-to-Faculty Incivility}

Analyzing survey data from 588 nursing faculty members from 40 states, Clark et al reported common uncivil behaviors included failing to uphold one's share of the workload, using cell phones or other handheld devices during meetings or class, putting down fellow faculty members, gossiping about colleagues, interrupting others, and challenging other colleagues' knowledge. ${ }^{5}$ In a review of nursing literature, Gallo identified additional uncivil faculty behaviors as losing patience, being incompetent, and making rude, condescending remarks. ${ }^{3}$ According to Wright and Hill, incivility among health sciences faculty members included giving colleagues the silent treatment, micromanaging subordinates, engaging in constant criticism, gossiping, excluding others, belittling others' work, and taking credit for others' work. ${ }^{8}$

\section{Workplace Bullying}

King and Piotrowski suggested bullying of adults by adults is a common experience in the workplace, especially in higher education settings where faculty members are seeking to gain tenure, promotion, or other rewards. ${ }^{9}$ Lampman surveyed 524 higher education professors and found that female professors reported more incidents of bullying than male professors. ${ }^{10}$ Incidentally, Lampman's study only addressed incidents where faculty members were bullied by students and not by other faculty members. ${ }^{10}$

\section{Faculty-to-Student Incivility}

In addition to faculty-to-faculty incivility, instructors can engage in uncivil behaviors directed toward students. ${ }^{1-3,11}$ Analyzing survey data containing short answer responses, Lasiter et al discovered that 133 out of $152(87.5 \%)$ nursing students experienced some type of uncivil treatment from didactic or clinical faculty members. ${ }^{11}$ Lasiter et al classified the 94 short answer responses provided by nursing students into four categories: in front of someone, talked to others about me, made me feel stupid, and I felt belittled. Of the 94 responses, $23(24.5 \%)$ students described situations where they were corrected, criticized, yelled at, or laughed at by nursing faculty members in the presence of patients, family members, classmates, or other nursing professionals. ${ }^{11}$ Only $6(6.4 \%)$ nursing students reported that they had overheard nursing faculty members discussing errors and mistakes they had made to others. ${ }^{11}$ Twenty-nine (30.9\%) nursing students indicated that they felt dumb, incapable, incompetent, or stupid as a result of actions or communications made by nursing faculty members. ${ }^{11}$ Finally, $51(54.3 \%)$ students felt belittled or unimportant when nursing faculty members lost their assignments, threatened to give low grades, did not reply to emails, laughed at or mimicked them, interrupted them, talked down to them, seemed uncaring, did not listen or ignored them, or suggested a different career path. ${ }^{11}$

Frey-Knepp and Gallo reported that students are often bothered by instructors who present lectures at a fast pace with little to no student involvement, act in a distant manner toward students, surprise students with unannounced assessments or unanticipated 
examination questions, and arrive late to class or cancel class without prior notice. ${ }^{2,3}$ Wright and Hill stated that allied health instructors who act in an uncivil manner may compromise their students' learning and interfere with the quality of training and instruction they are providing. ${ }^{8}$ This issue is critical when considering patient care may be potentially compromised.

Considering the lack of research specific to imaging sciences and radiation therapy, there is a need to conduct a study that examines the prevalence of incivility among medical imaging educators. Such a study might allow educators to see how behaviors they do not consider to be uncivil may adversely affect students and colleagues and interfere with classroom learning and workplace productivity.

\section{METHODOLOGY}

Using a survey research design, this study examined the perceptions of incivility among educators teaching in radiography programs accredited by the Joint Review Committee on Education in Radiologic Technology (JRCERT). Consent was implied when the radiography educator participants started the electronic survey. In addition to explicit instructions, the participants read statements detailing that their participation in this study was voluntary, their identity would remain anonymous, and their privacy and confidentiality would not be compromised. Institutional review board (IRB) approval was granted by Midwestern State University (IRB \#17060701). Specifically, the study addressed:

1. The prevalence (severity and frequency) of incivility as perceived among radiography educators in the United States within their respective programs.

2. The relationship, if any, between perceived severity of faculty incivility and educator age and years of teaching experience.

3. The association, if any, between perceived severity of faculty incivility and educator education level, position, and institution type.

\section{Instrumentation}

Because an appropriate survey was not identified in the literature review, the researchers created a survey instrument to explore the severity and frequency of incivility as perceived among radiography educators. The behaviors listed on the survey instrument were identified from the literature pertaining to faculty incivility in allied health education and higher education in general. The survey instrument contained 11 questions and was uploaded into survey software available for use by employees of Midwestern State University. To assess measurement validity, the survey instrument was piloted to 8 imaging sciences educators who each had multiple years of higher education teaching experience. The imaging sciences educators were asked to review the survey instrument to make certain the content aligned with the study's purpose and methodology. They were also asked to review each survey item to make certain the wording was understandable by the intended participants. Those experienced educators made suggestions for simplifying and rewriting some questions for better understanding and improved wording, and they also provided additional uncivil behaviors to include on the survey. Once those suggested changes were made, a small sample of 30 imaging sciences educators were asked to complete the survey to assess reliability of the instrument. Cronbach's alpha was used to measure the reliability of the instrument, and an analysis using IBM's SPSS software revealed an internal consistency of $a=0.792$. A reliability coefficient of 0.70 or higher indicates an acceptable level of reliability in most research.

After pilot testing was completed, detailed instructions along with a link to the survey were sent to the participants. The survey defined faculty incivility as those behaviors that disrupt student learning and hinder workplace productivity. The instructors required the participants to consider incidents of incivility within their radiography departments. Specific survey items required the radiography educator participants to rate how serious faculty behaviors were on a scale of 1 to 4 ( $1=$ not a problem, $2=$ minor problem, $3=$ moderate problem, and $4=$ major problem) if they occurred or were to occur in their radiography departments and how often those behaviors occur within their radiography department on a scale of 1 to 4 ( $1=$ never, $2=$ rarely, $3=$ occasionally, and 4 = frequently). The participants were also given the opportunity to add any severe or frequent faculty behaviors not identified on the survey. In addition to demographic questions, the participants indicated overall how serious they thought faculty incivility was in radiography education as not serious, somewhat serious, serious, or extremely serious. Completion of the survey was estimated to take no longer than 10 minutes.

\section{Participants}

The participants in this study included educators in radiography programs accredited by the JRCERT. The JRCERT personnel had previously provided a spreadsheet containing contact information and email addresses for radiography program directors, clinical coordinators, and didactic instructors for a research study involving student incivility in radiography education. The same spreadsheet was used for this study. The use of the contact list for this study was consistent with the terms agreed upon in the previous study. The spreadsheet contained a total of 1,401 email addresses, and all respective personnel were invited to participate 
in this study. The email sent to the participants contained the survey link, the purpose of the research study, detailed instructions on completing the survey, and a statement guaranteeing the participants' identity and privacy would be not be compromised. Participation was voluntary, and consent was implied when the participants clicked on the link and began the survey.

\section{Data Collection and Analysis}

After approval to conduct this study was granted from Midwestern State University's IRB and changes to the survey instrument were made based on the feedback received from the pilot study, the survey link was active for a total of 8 weeks. Because multiple out-of-office emails were received (the email to complete the survey was sent in June 2017), the researchers decided to extend the availability of the survey. The response rate did not change after 6 weeks so the survey link was deactivated after 8 weeks. The survey software only allowed 1 user submission per internet protocol address.

The results were exported to SPSS software and saved to an external storage device. SPSS software was used to perform the data analysis procedures, including descriptive statistics on the perceived severity and frequency of faculty incivility; Spearman rank correlation coefficients on the relationships between the perceived severity of faculty incivility and educator age and years of teaching experience; and Pearson chi-square calculations on the associations between the perceived severity of faculty incivility and educator education level, position, and institution type. The SPSS data file and output tables were saved to an external storage device and stored in a locked filing cabinet with limited personnel access. The external storage device will be reformatted after 3 years per Midwestern State University's IRB protocols.

\section{RESULTS}

When the email was sent to the participants in June 2017, 69 emails were returned undeliverable, 60 out-of-office responses were received, 1 individual supplied 2 additional email addresses of radiography instructors who were not listed on the initial spreadsheet, and 1 individual reported a change in employment and could not complete the survey. Because of these conditions, a total of 1,333 email addresses received an invitation to complete the survey. Of those 1,333 participants, 342 responses were received; however, 102 surveys were not fully completed and were discarded. A total of 240 completed surveys were analyzed for this study, resulting in a participant response rate of $18 \%(240 / 1,333)$.

Among the 240 participants, the majority were program directors (52.5\%), women $(77.9 \%)$, worked at a community college (38.8\%), and held a master's degree (74.2\%). The average age of the participants was 50.6 years, and the average years of teaching experience was 17.1. See Table 1 for the participant demographic characteristics. These demographic data are similar to results obtained from a previous study involving student incivility as perceived by radiography educators. ${ }^{7}$

Using a scale of 1 to 4 , the participants in this study considered their perceptions of faculty incivility among radiography educators within their respective departments to be a minor problem. Only 40.4\% (97/240) of the participants in this study perceived that the severity of incivility was not a problem. The majority of the participant perceived civility to be an issue with $23.8 \%(57 / 240)$ reporting a minor problem; $39 / 240(16.3 \%)$ reporting it was a moderate problem; and 47/240 (19.6\%) believed faculty incivility is a major problem among radiography educators in the United States.

\section{Severity and Frequency}

The study participants indicated how severe they perceived faculty behaviors to be if they occurred or were to occur within their departments. The mean and standard deviation for each behavior are listed in Table 2 from most to least severe. The behaviors that participants in this study thought were most severe included bullying others, belittling or humiliating others, and intimidating others. Other severe faculty behaviors identified multiple times by the study participants that were not listed on the survey included:

- $\quad$ Allowing students to access an instructor's personal social media page.

- $\quad$ Being racist.

- Drinking with students outside of class.

- Having excessive absences.

- Having poor hygiene.

- Having sexual relations with students.

- Not reporting leave time.

- $\quad$ Not supporting or following program policies or procedures.

- $\quad$ Recording others without their knowledge.

- Telling students one thing, then telling other faculty members and staff something different.

- Using alcohol or drugs during work hours. 
The study participants indicated how frequently they witnessed uncivil faculty behaviors in their radiography programs. The mean and standard deviation for each behavior are listed in Table 3 from most to least frequent. The faculty behaviors that participants in this study witnessed most frequently included arriving late for class or meetings, showing favoritism towards certain students, and having poor communication skills. Other frequent faculty behaviors identified multiple times by the study participants that were not listed on the survey included:

- Gossiping.

- Hanging out with students outside of class.

- Spending the majority of the day socializing instead of working.

- Texting students.

- Using cell phones to record conversations with others without their knowledge.

\section{Severity of Faculty Incivility and Age and Years of Teaching Experience}

Spearman rank correlation coefficient tests were conducted in SPSS to determine the relationship between perceived severity of faculty incivility and educator age and years of teaching experience. Although a significant relationship was found between perceived severity of faculty incivility and instructor age, $r_{s}(238)=-0.185, p=0.004$, it was a very weak negative correlation with a small effect size. Incidentally, no significant relationship was identified between perceived severity of faculty incivility and years of teaching experience: $r_{s}(238)=-.091, p=0.159$.

\section{Severity of Faculty Incivility and Education Level, Position, and Institution Type}

Pearson chi-square tests were conducted in SPSS to determine any association between perceived severity of faculty incivility and education level, position, and type of institution. The minimum expected values were met, requiring no further testing. No significant association was found between perceived severity of faculty incivility and education level $\left[X^{2}=5.5(9, n=240), p=\right.$ 0.79]; position [ $\left.X^{2}=12.2(12, n=240), p=0.43\right]$; and institution type $\left[X^{2}=7.5(12, n=240), p=0.82\right]$. See Tables 4,5 , and 6 for the cross-tabulations on perceived severity of faculty incivility and participants' education level, position, and institution type, respectively.

\section{DISCUSSION}

The 240 participants in this study included program directors, clinical coordinators, didactic instructors, and clinical instructors from JRCERT-accredited radiography programs. The majority of the participants perceived incivility to be an issue with $23.8 \%(57 / 240)$ reporting a minor problem; $39 / 240(16.3 \%)$ said it was a moderate problem; and $47 / 240(19.6 \%)$ believed faculty incivility is a major problem among radiography educators in the United States. The participants identified the most severe uncivil faculty behaviors as bullying others, belittling or humiliating others, and intimidating others; less severe uncivil faculty behaviors were not engaging in scholarly activities or service opportunities, not being available outside of class, and dressing inappropriately. The participants identified the most frequent uncivil faculty behaviors as arriving late for class or meetings, showing favoritism towards certain students, and having poor communication skills; less frequent uncivil faculty behaviors were sexually harassing others, refusing to accept teaching assignments, and using social media inappropriately. These behaviors were similar to findings in the literature involving nursing, allied health, and higher education instructors. $3,5,8,9$

There was a significant relationship between perceived severity of faculty incivility and age of radiography educators. The relationship was classified as a very weak negative relationship, suggesting as age increased, the perceived severity of faculty incivility slightly decreased and vice versa. Should this low magnitude relationship be confirmed with additional studies, this relationship may be explained by the fact that older, established educators may be more able and willing to handle incivility and act appropriately. Considering the small effect size, a larger sample size is needed to confirm this finding. Although no significant relationship was found between perceived severity of faculty incivility and years of teaching experience, the result also demonstrated a very weak negative relationship.

\section{Limitations and Assumptions}

This study was limited in several ways. First, the sample size makes it difficult to generalize the findings to all educators in JRCERTaccredited radiography programs. Although a response rate of 18\% (240 participants) was obtained, 102 individuals did not complete the survey for unknown reasons. Their input might have provided additional information to depict a better representation of incivility among radiography educators in the United States. Moreover, there could be response bias with only those who are aware of uncivil behaviors taking the time to answer the survey. The study was also limited by the use of self-reporting data. It is possible that some participants might not have answered the survey questions honestly in an attempt to not disclose their engagement in any type of uncivil behaviors directed toward others. Furthermore, since the majority of the radiography educators 
participating in this study were women $(n=187,77.9 \%)$, generalizing gender implications similar to Lampman's study is not practical. ${ }^{10}$

An extension of this project may include examining the contributors of faculty incivility along with prevention techniques. In addition, this study did not differentiate between faculty-to-faculty and faculty-to-student incivility. A future research project evaluating students' perceptions of faculty incivility would provide a better illustration of faculty-to-student incivility. Finally, it was assumed that faculty incivility was occurring among radiography educators in the United States and that those educators would be willing to openly share their experiences and respond honestly.

\section{CONCLUSION}

According to the participants in this study, faculty incivility, although minor, is perceived to be occurring among radiography educators in the United States. Some uncivil faculty behaviors documented among nursing and other allied health educators are being witnessed among radiography educators. Some of these behaviors include arriving late for class or meetings, having poor communication skills, not being prepared for class, and belittling or humiliating others. This study revealed a very weak negative correlation between perceived severity of faculty incivility and educator age and years of teaching experience. The possibility of using older, more experienced educators to help their younger, less experienced colleagues handle incivility should be considered. No association was found between perceived severity of faculty incivility and educator level of education, position, and institution type.

Ultimately, acknowledging faculty incivility by managing it effectively or preventing it altogether, as indicated in the literature, is crucial to avoid future issues that may occur. No original research was identified examining incivility among radiography educators. This study provides a foundation for future research to address other aspects of incivility among imaging sciences and radiation therapy educators, including other imaging modalities, students' perceptions of faculty incivility, and contributors to faculty incivility along with preventative techniques.

\section{REFERENCES}

1. Alt D, Itzkovich Y. Adjustment to college and perceptions of faculty incivility. Curr Psychol. 2016;35(4):657-66. https://doi.org/10.1007/s12144-015-9334-x

2. Frey-Knepp KA. Understanding student and faculty incivility in higher education. J Effective Teach. 2012;12(1):33-46.

3. Gallo VJ. Incivility in nursing education: a review of the literature. Teach Learn Nurs. 2012;7(2):62-6. http://dx.doi.org/10.1016/j.teln.2011.11.006

4. American Nurses Association. Violence, Incivility, \& Bullying. https://www.nursingworld.org/practice-policy/workenvironment/violence-incivility-bullying/. Accessed March 1, 2018.

5. Clark CM, Olender L, Kenski D, Cardoni C. Exploring and addressing faculty-to-faculty incivility: a national perspective and literature review. J Nurs Educ. 2013;52(4):211-8. doi:10.3928/01484834-20130319-01 [PMID: 23495699]

6. Clark CM. National study on faculty-to-faculty incivility: strategies to foster collegiality and civility. Nurs Educ. 2013;38(3):98102. doi:10.1097/NNE.0b013e31828dc1b2 [PMID: 23608907]

7. Clark KR. Student incivility in radiography education. Radiol Tech. 2017;88(6):590-602. [PMID: 28900046]

8. Wright M, Hill LH. Academic incivility among health sciences faculty. Adult Learn. 2015;26(1):14-20.

doi:10.1177/1045159514558410

9. King C, Piotrowski C. Bullying of educators by educators: incivility in higher education. Contemporary Issues Educ Res. 2015;8(4):257-62. https://doi.org/10.19030/cier.v8i4.9434

10. Lampman C. Women faculty at risk: U.S. professors report on their experiences with student incivility, bullying, aggression, and sexual attention. NASPA J Women Higher Educ. 2012;5(2):184-208. doi:10.1515/njawhe-2012-1108 11. Lasiter S, Marchiondo L, Marchiondo K. Student narratives of faculty incivility. Nurs Outlook. 2012;60(3):121-6. doi:10.1016/j.outlook.2011.06.001 [PMID: 21840556] 
Table 1: Participant Demographic Characteristics

\begin{tabular}{|l|l|}
\hline Characteristic & $\mathbf{n}(\%)$ \\
\hline Position & $9(3.8)$ \\
\hline Clinical and didactic instructor & $6(2.5)$ \\
\hline Clinical instructor & $33(13.8)$ \\
\hline Didactic instructor & $66(27.5)$ \\
\hline Clinical coordinator & $126(52.5)$ \\
\hline Program director & $9(3.8)$ \\
\hline Facility & $42(17.5)$ \\
\hline Proprietary institution & $18(7.5)$ \\
\hline Hospital & $93(38.8)$ \\
\hline Technical college/institute & $78(32.5)$ \\
\hline Community college & \multicolumn{2}{|l|}{} \\
\hline College/university & $53(22.1)$ \\
\hline Gender & $187(77.9)$ \\
\hline Male & $1(0.4)$ \\
\hline Female & $40(16.7)$ \\
\hline Level of Education & $178(74.2)$ \\
\hline Associate & $21(8.8)$ \\
\hline Bachelor's &
\end{tabular}

Table 2: Perceived Severity of Faculty Behaviors

\begin{tabular}{|l|l|l|}
\hline Behavior & Mean & Standard Deviation \\
\hline Bullying others & 3.45 & 1.10 \\
\hline Belittling or humiliating others & 3.43 & 1.06 \\
\hline Intimidating others & 3.37 & 1.07 \\
\hline Discrediting others to students & 3.35 & 1.09 \\
\hline Sexually harassing others & 3.34 & 1.22 \\
\hline Being unprepared for class & 3.31 & 1.09 \\
\hline Making rude, condescending remarks to others & 3.29 & 1.12 \\
\hline Lacking content knowledge & 3.22 & 1.08 \\
\hline Using social media inappropriately & 3.21 & 1.13 \\
\hline Showing disinterest in students & 3.18 & 1.11 \\
\hline Showing favoritism towards certain students & 3.17 & 1.09 \\
\hline Discounting other faculty members' experience & 3.13 & 1.09 \\
\hline Having poor communication & 3.13 & 1.03 \\
\hline Circumventing appropriate chain of command & 3.08 & 1.08 \\
\hline $\begin{array}{l}\text { Challenging other faculty members' knowledge and } \\
\text { credibility }\end{array}$ & 3.06 & 1.09 \\
\hline Using vulgarity & & \\
\hline Having a poor teaching style & 3.02 & 1.16 \\
\hline Having poor classroom management skills & 3.01 & 1.00 \\
\hline Refusing to work with others & 3.00 & 1.02 \\
\hline Arriving late for class or meetings & 2.98 & 1.12 \\
\hline Canceling class without prior notice & 2.93 & 1.02 \\
\hline Refusing to accept teaching assignments & 2.91 & 1.10 \\
\hline Dressing inappropriately & 2.88 & 1.15 \\
\hline Not being available outside of class & 2.82 & 1.07 \\
\hline $\begin{array}{l}\text { Not engaging in scholarly activities or service } \\
\text { opportunities }\end{array}$ & 2.78 & 1.03 \\
\hline & 2.43 & 0.88 \\
\hline
\end{tabular}


Table 3: Frequency of Faculty Behaviors

\begin{tabular}{|l|l|l|}
\hline Behavior & Mean & Standard Deviation \\
\hline Arriving late for class or meetings & 2.43 & 0.83 \\
\hline Showing favoritism towards certain students & 2.21 & 0.98 \\
\hline Having poor communication & 2.19 & 0.90 \\
\hline Being unprepared for class & 2.18 & 0.87 \\
\hline Having a poor teaching style & 2.14 & 0.89 \\
\hline $\begin{array}{l}\text { Not engaging in scholarly activities or service } \\
\text { opportunities }\end{array}$ & 2.13 & 0.91 \\
\hline Having poor classroom management skills & & \\
\hline Circumventing appropriate chain of command & 2.13 & 0.88 \\
\hline Lacking content knowledge & 2.01 & 0.95 \\
\hline Making rude, condescending remarks to others & 1.96 & 0.89 \\
\hline $\begin{array}{l}\text { Challenging other faculty members' knowledge and } \\
\text { credibility }\end{array}$ & 1.93 & 0.96 \\
\hline Discounting other faculty members' experience & 1.93 & 0.94 \\
\hline Belittling or humiliating others & 1.92 & \\
\hline Discrediting others to students & 1.91 & 0.96 \\
\hline Not being available outside of class & 1.88 & 0.96 \\
\hline Intimidating others & 1.86 & 0.96 \\
\hline Canceling class without prior notice & 1.80 & 0.82 \\
\hline Showing disinterest in students & 1.78 & 0.96 \\
\hline Dressing inappropriately & 1.72 & 0.79 \\
\hline Bullying others & 1.71 & 0.82 \\
\hline Using vulgarity & 1.69 & 0.90 \\
\hline Refusing to work with others & 1.66 & 0.97 \\
\hline Using social media inappropriately & 1.62 & 0.84 \\
\hline Refusing to accept teaching assignments & 1.60 & 0.84 \\
\hline Sexually harassing others & 1.47 & 0.86 \\
\hline Using social media inappropriately & 1.18 & 0.75 \\
\hline Refusing to accept teaching assignments & 1.60 & 0.50 \\
\hline Sexually harassing others & 1.47 & 0.86 \\
\hline & 1.18 & 0.75 \\
\hline
\end{tabular}

Table 4: Cross-tabulation of Perceived Severity of Faculty Incivility and Level of Education of Radiography Educators

\begin{tabular}{|l|l|l|l|l|l|}
\hline & \multicolumn{4}{|l|}{ Level of Education of Radiography Educators } \\
\hline Perceived Severity of Faculty Incivility & $\begin{array}{l}\text { Associate } \\
\mathrm{n}(\%)\end{array}$ & $\begin{array}{l}\text { Bachelor's } \\
\mathrm{n}(\%)\end{array}$ & $\begin{array}{l}\text { Master's } \\
\mathrm{n}(\%)\end{array}$ & $\begin{array}{l}\text { Doctorate } \\
\mathrm{n}(\%)\end{array}$ & $\begin{array}{l}\text { Total } \\
\mathrm{n}(\%)\end{array}$ \\
\hline Not a problem & $1(0.4)$ & $17(7.1)$ & $73(30.4)$ & $6(2.5)$ & $97(40.4)$ \\
\hline Minor problem & $0(0.0)$ & $12(5.0)$ & $39(16.3)$ & $6(2.5)$ & $57(23.8)$ \\
\hline Moderate problem & $0(0.0)$ & $6(2.5)$ & $28(11.7)$ & $5(2.1)$ & $39(16.3)$ \\
\hline Major problem & $0(0.0)$ & $5(2.1)$ & $38(15.8)$ & $4(1.7)$ & $47(19.6)$ \\
\hline Total & $1(0.4)$ & $40(16.7)$ & $178(74.2)$ & $21(8.8)$ & $240(100)$ \\
\hline
\end{tabular}


Table 5: Cross-tabulation of Perceived Severity of Faculty Incivility and Position of Radiography Educators

\begin{tabular}{|l|l|l|l|l|l|l|}
\hline & \multicolumn{5}{|l|}{ Position of Radiography Educators } \\
\hline $\begin{array}{l}\text { Perceived Severity } \\
\text { of Faculty Incivility }\end{array}$ & $\begin{array}{l}\text { Program } \\
\text { director } \\
\mathrm{n}(\%)\end{array}$ & $\begin{array}{l}\text { Clinical } \\
\text { coordinator } \\
\mathrm{n}(\%)\end{array}$ & $\begin{array}{l}\text { Didactic } \\
\text { instructor } \\
\mathrm{n}(\%)\end{array}$ & $\begin{array}{l}\text { Clinical } \\
\text { instructor } \\
\mathrm{n}(\%)\end{array}$ & $\begin{array}{l}\text { Both clinical and } \\
\text { didactic instructor } \\
\mathrm{n}(\%)\end{array}$ & $\begin{array}{l}\text { Total } \\
\mathrm{n}(\%)\end{array}$ \\
\hline Not a problem & $52(21.7)$ & $26(10.8)$ & $14(5.8)$ & $2(0.8)$ & $3(1.3)$ & $97(40.4)$ \\
\hline Minor problem & $27(11.3)$ & $14(5.8)$ & $12(5.0)$ & $3(1.3)$ & $1(0.4)$ & $57(23.8)$ \\
\hline Moderate problem & $19(7.9)$ & $14(5.8)$ & $2(0.8)$ & $1(0.4)$ & $3(1.3)$ & $39(16.3)$ \\
\hline Major problem & $28(11.7)$ & $12(5.0)$ & $5(2.1)$ & $0(0.0)$ & $2(0.8)$ & $47(19.6)$ \\
\hline Total & $126(52.5)$ & $66(27.5)$ & $33(13.8)$ & $6(2.5)$ & $9(3.8)$ & $240(100)$ \\
\hline
\end{tabular}

Table 6: Cross-tabulation of Perceived Severity of Faculty Incivility and Institution Type of Radiography Educators

\begin{tabular}{|l|l|l|l|l|l|l|}
\hline & & \multicolumn{6}{|l|}{ Institution Type of Radiography Educators } \\
\hline $\begin{array}{l}\text { Perceived Severity } \\
\text { of Faculty Incivility }\end{array}$ & $\begin{array}{l}\text { College/ } \\
\text { university } \\
\mathrm{n}(\%)\end{array}$ & $\begin{array}{l}\text { Community } \\
\text { college } \\
\mathrm{n}(\%)\end{array}$ & $\begin{array}{l}\text { Technical } \\
\text { college/institute } \\
\mathrm{n}(\%)\end{array}$ & $\begin{array}{l}\text { Hospital } \\
\mathrm{n}(\%)\end{array}$ & $\begin{array}{l}\text { Proprietary } \\
\text { institution } \\
\mathrm{n}(\%)\end{array}$ & $\begin{array}{l}\text { Total } \\
\mathrm{n}(\%)\end{array}$ \\
\hline Not a problem & $29(12.1)$ & $42(17.5)$ & $9(3.8)$ & $13(5.4)$ & $4(1.7)$ & $97(40.4)$ \\
\hline Minor problem & $20(8.3)$ & $19(7.9)$ & $4(1.7)$ & $13(5.4)$ & $1(0.4)$ & $57(23.8)$ \\
\hline Moderate problem & $16(6.7)$ & $14(5.8)$ & $1(0.4)$ & $6(2.5)$ & $2(0.8)$ & $39(16.3)$ \\
\hline Major problem & $13(5.4)$ & $18(7.5)$ & $4(1.7)$ & $10(4.2)$ & $2(0.8)$ & $47(19.6)$ \\
\hline Total & $78(32.5)$ & $93(38.8)$ & $18(7.5)$ & $42(17.5)$ & $9(3.8)$ & $240(100)$ \\
\hline
\end{tabular}

\section{--SURVEY INSTRUMENT--}

\section{Incivility Among Radiography Educators in the United States}

This research study explores the prevalence of faculty incivility among radiography educators in the United States.

These survey items are based on an extensive review of literature and data collected from various research articles. Incivility is defined as those faculty behaviors that disrupt student learning and hinder workplace productivity.

Completion of this survey is voluntary; consent is implied when you begin the survey. Your identity, privacy, and confidentiality will not be compromised, and all results will remain anonymous. 
How serious do you consider the following faculty behaviors to be?

\begin{tabular}{|c|c|c|c|c|}
\hline & Not a problem & $\begin{array}{l}\text { Minor } \\
\text { problem }\end{array}$ & $\begin{array}{l}\text { Moderate } \\
\text { problem }\end{array}$ & $\begin{array}{l}\text { Major } \\
\text { problem }\end{array}$ \\
\hline Arriving late for class or meetings & 0 & 0 & 0 & 0 \\
\hline Being unprepared for class & 0 & 0 & 0 & 0 \\
\hline Belittling or humiliating others & 0 & 0 & 0 & 0 \\
\hline Bullying others & 0 & 0 & 0 & 0 \\
\hline Canceling class without prior notice & 0 & 0 & 0 & 0 \\
\hline Challenging other faculty's knowledge and credibility & 0 & 0 & 0 & 0 \\
\hline Circumventing appropriate chain of command & 0 & 0 & 0 & 0 \\
\hline Discounting other faculty's experience & 0 & 0 & 0 & 0 \\
\hline Discrediting others to students & 0 & 0 & 0 & 0 \\
\hline Dressing inappropriately & 0 & 0 & 0 & 0 \\
\hline Having a poor teaching style & 0 & 0 & 0 & 0 \\
\hline Having poor classroom management skills & 0 & 0 & 0 & 0 \\
\hline Having poor communication & 0 & 0 & 0 & 0 \\
\hline Intimidating others & 0 & 0 & 0 & 0 \\
\hline Lacking content knowledge & 0 & 0 & 0 & 0 \\
\hline Making rude, condescending remarks to others & 0 & 0 & 0 & 0 \\
\hline Not being available outside of class & 0 & 0 & 0 & 0 \\
\hline $\begin{array}{l}\text { Not engaging in scholarly activities or service } \\
\text { opportunities }\end{array}$ & 0 & 0 & 0 & 0 \\
\hline Refusing to accept teaching assignments & 0 & 0 & 0 & 0 \\
\hline $\begin{array}{l}\text { Refusing to work with others (team-teaching, research, } \\
\text { and service) }\end{array}$ & 0 & 0 & 0 & 0 \\
\hline Sexually harassing others & 0 & 0 & 0 & 0 \\
\hline Showing disinterest in students & 0 & 0 & 0 & 0 \\
\hline Showing favoritism towards certain students & 0 & 0 & 0 & 0 \\
\hline Using social media inappropriately & 0 & 0 & 0 & 0 \\
\hline Using vulgarity & 0 & 0 & 0 & 0 \\
\hline
\end{tabular}

Enter any other faculty behaviors (not listed above) you consider a major problem:

(C) The Internet Journal of Allied Health Sciences and Practice, 2019 
How often have you observed the following faculty behaviors in your radiography department?

\begin{tabular}{|c|c|c|c|c|}
\hline & Never & Rarely & Occasionally & Frequently \\
\hline Arriving late for class or meetings & 0 & 0 & 0 & 0 \\
\hline Being unprepared for class & 0 & 0 & 0 & 0 \\
\hline Belittling or humiliating others & 0 & 0 & 0 & 0 \\
\hline Bullying others & 0 & 0 & 0 & 0 \\
\hline Canceling class without prior notice & 0 & 0 & 0 & 0 \\
\hline Challenging other faculty's knowledge and credibility & 0 & 0 & 0 & 0 \\
\hline Circumventing appropriate chain of command & 0 & 0 & 0 & 0 \\
\hline Discounting other faculty's experience & 0 & 0 & 0 & 0 \\
\hline Discrediting others to students & 0 & 0 & 0 & 0 \\
\hline Dressing inappropriately & 0 & 0 & 0 & 0 \\
\hline Having a poor teaching style & 0 & 0 & 0 & 0 \\
\hline Having poor classroom management skills & 0 & 0 & 0 & 0 \\
\hline Having poor communication & 0 & 0 & 0 & 0 \\
\hline Intimidating others & 0 & 0 & 0 & 0 \\
\hline Lacking content knowledge & 0 & 0 & 0 & 0 \\
\hline Making rude, condescending remarks to others & 0 & 0 & 0 & 0 \\
\hline Not being available outside of class & 0 & 0 & 0 & 0 \\
\hline $\begin{array}{l}\text { Not engaging in scholarly activities or service } \\
\text { opportunities }\end{array}$ & 0 & 0 & 0 & 0 \\
\hline Refusing to accept teaching assignments & 0 & 0 & 0 & 0 \\
\hline $\begin{array}{l}\text { Refusing to work with others (team-teaching, research, } \\
\text { and service) }\end{array}$ & 0 & 0 & 0 & 0 \\
\hline Sexually harassing others & 0 & 0 & 0 & 0 \\
\hline Showing disinterest in students & 0 & 0 & 0 & 0 \\
\hline Showing favoritism towards certain students & 0 & 0 & 0 & 0 \\
\hline Using social media inappropriately & 0 & 0 & 0 & 0 \\
\hline Using vulgarity & 0 & 0 & 0 & 0 \\
\hline
\end{tabular}

Overall, how serious is faculty incivility in radiography education in the United States?

O Not serious

O Somewhat serious

O Serious

O Extremely serious 
Which role best describes your current position?

O Program director

O Clinical coordinator

O Didactic instructor

O Clinical instructor

O Other:

In which type of institution do you work?

O College/university

O Community college

O Technical college/institute

O Hospital

O Proprietary institution?

O Other:

How many years of teaching experience do you have?

What is your gender?

What is your age?

What is your highest level of education?

O Doctoral degree

O Master's degree

O Bachelor's degree

O Associate's degree

0 Other: 